Państwowy Białoruski Uniwersytet Kultury i Sztuki

Mińsk

https://orcid.org/0000-0002-1783-9596

\title{
Ценные предметы в белорусских народных песнях с родины Адама Мицкевича
}

Адам Бернард Мицкевич (1798-1855) родился на земле Гродненского Понеманья - уникального историко-этнографического региона, заселённого много тысяч лет назад (со времен палеолита) и объединяющего истоки культур сразу нескольких народов (литовцев, белорусов и поляков), а также - судьбы, связанных с его этнической историей средневековых мигрантов на его территории (евреев, татар и цыган), совместно проживающих в данном регионе и сейчас. «Пёстрый котёл» народов и культур на Понеманье всегда трактовался по-разному, возможно, поэтому местного уроженца А. Мицкевича сегодня называют «своим» поэтом и поляки (Adam Mickiewicz), и белорусы (Адам Міцкевіч), и литовцы (Adomas Mickevičius). Это примечательный и любопытный факт, а идентичность, отражённая в первых произведениях А. Мицкевича, очевидно связана с субкультурой его малой родины, издавна зафиксированной в её устной литературе (песнях, сказках, легендах), причём тезаурус материальных ценностей, упоминаемый в ней, до сих пор специально не рассматривался. Поэтому ц е л ь ю данного исследования является характеристика художественного контекста ченных предметов, описанных в белорусских народных песнях, зафиксированньх в окрестностях родинь Адама Мичкевича с позииий искусствоведения и антикварного дела.

Фольварок Заосье (сегодня - деревня Заосье Барановичского района Брестской области Беларуси), где, согласно версиям большинства биографов, родился А. Мицкевич (по определению классика бе- 
лорусской литературы Владимира Короткевича, поэт-титан, вследствие собственной бедности подаренный нами Польшер), является, фактически, окрестностями современных Барановичей. Причем фольварок имеет явную направленность по оси «запад-восток» к окрестностям родового гнезда Радзивиллов, ренессансного Несвижа, а также примыкает по оси «север-юг», развёрнутой в направлении села Ва́левка (берег озера Свитязь), к широко известной уже в Средневековье Новогрудчине. Озеро Свитязь - это центр Новогрудской возвышенности, а расстояние между границами околиц Заосья, Свитязи, Новогрудка и Несвижа и составляющими «малую родину великого поэта» 2 всего-навсего около нескольких десятков километров. Политические карты, а также «административная неразбериха» времён Великого Княжества Литовского, Речи Посполитой, Российской империи, СССР, суверенной Беларуси неоднократно делили и разъединяли данную часть Понеманья, но, как показало время, его культура, искусство и духовность, в определённой степени, самодостаточны и едины.

Широкая известность настигла А. Мицкевича после публикации в его поэтическом сборнике 1822 года «Баллады и романсы» (кстати, по мнению искусствоведов, положившем начало польскому романтизм $y^{3}$ ) мистико-романтической баллады «Свитязянка». Примечательно, что именно панорама родных ландшафтов А. Мицкевича, а также аура звучащих над Свитязью песен, музыкальных мотивов, легенд и мифов, неуловимо наполнила «Свитязянку» подлинностью и колоритом Понеманья. Отказ же в текстологии и фабуле баллады «от просветительского рационализма ("мертвых истин") ради "чувства", "веры", “сердца", ради фантастики народных верований и романтического тезиса о таинственной связи "видимого" и "невидимого" миров» 4 уверенно ввёл Адама Мицкевича в круг ведущих поэтов новой эпохи искусства XIX века - эпохи Романтизма.

Новая эстетика и мировоззрение, отраженные в поэзии А. Мицкевича, не могли не быть сформированы под влиянием материальной и духовной культуры, которые его окружали со времён отрочества и юно-

1 В. Короткевич, Чёрный замок Ольшанский. Дикая охота короля Стаха, Минск 1984 , c. 6.

2 Г. Улитёнок, В. Лиходедов, В поисках утраченного: малая родина великого Адама Миикевич, «Беларусь сегодня», 2018, 03 марта 2018, с. 8.

3 А. Мицкевич, Стихотворения. Поэмь, пер. с пол., вступ. статья, сост. и прим.

Б. Стахеева, Москва 1968, с. 2.

4 Там же, с. 2. 
сти. С фольклорными традициями Понеманья А. Мицкевича знакомил еще с детства служащий его родителей Власий - вероятно, одарённый носитель местной фольклорной традиции. А, собственно, с сюжетом «Свитязянки», связанным с мотивом затопленных городов и сёл, мистически всплывающих в определённое время (обычно на Купалье), а также со средневековой историей Великого Княжества Литовского, А. Мицкевич и его юношеская «платоническая любовь» Марыля Верещако (Marianna Ewa Wereszczakówna) совершенно случайно познакомились на берегу Свитязи летом 1819 года, слушая то ли рассказ местного рыбака ${ }^{5}$, то ли (по косвенным данным) песню музыканта, аккомпанирующего себе на неком струнном музыкальном инструменте (колёсной лире, цитре либо гуслях).

Блестящий отечественный историк Митрофан Довнар-Запольский (1867-1934), характеризуя первые баллады поэта, отмечает: «Эти баллады целиком покоятся на известных Мицкевичу сюжетах народной поэзии. О сюжете "Свитязянки" сам Мицкевич говорит, что он пользуется народным преданием, по которому на поэтических берегах Свитязи появляются русалки. Отдельные аксессуары “Свитязянки" рознятся от народных преданий, но эти аксессуары Мицкевич берет из других народных произведений, заимствует оттуда эпитеты, сравнения, даже обороты речи» ${ }^{6}$.

Будучи в то время студентом Виленского университета и посещая лекции наиболее выдающихся профессоров того периода, А. Мицкевич уже искал в фольклоре не только сюжетно-образной свежести (использование фольклорных мотивов было избирательным, основанньц на переработке, стилизачии, контаминачии) - поэта привлекал в народном художественном мылилении, прежде всего, нравственный аспект. Фантастический мир баллад, в котором всегда проведена чёткая граница между добром и злом, где находили возмездие предательство, неверность, душевная чёрствость, а за обиженного вступались сверхъестественньее сильи, - был миром строгих нравственных требований, миром, романтически противопоставленным окружающей действительности.

5 А. Варрава, Шлях Мицкевича. Часть 3. [Elektronny resurs]. - Rezhym dostupu: https://planetabelarus.by/publications/shlyakh-mitskevicha-chast-3/. - Data dostupu: 12.02 .2021 .

6 М. Довнар-Запольский, История Белоруссии, Минск 2005, с. 94.

7 А. Мицкевич, Стихотворения. Поэмь / пер. с пол., вступ. статья, сост. и прим.

Б. Стахеева, Москва 1968, с. 2. 
Романтическое, в определенной степени иррационально-мистическое, связанное с народной мифологией мировоззрение обеспечивало, по мнению поэта, «возможность проникновения в такие сферы, которые являются недоступными эмпирическому знанию, но открыты народной общности, не испорченной воздействием цивилизации, сохранившей естественные начала и связи» ${ }^{8}$. Возможно, об этом с молодым Мицкевичем, посетившим Веймар в 1829 г., более двух часов дискутировал Иоганн Вольфганг фон Гёте (1749-1832), «патриарх европейских поэтов» того времени, а также рейхсминистр немецкого Герцогства Саксен-Веймар, обычно выделявший на аудиенцию своим посетителям не более двадцати минут 9 .

Со времён создания «Свитязянки» прошло уже около двухсот лет, но носители местной фольклорной традиции, передаваемой устным путём, всё это время не забывали свои предания и песни. Гродненское Понеманье хранит свою народную культуру, а предметы, упоминаемые в фольклоре данного региона, вероятно, могут помочь в проникновении в атмосферу мировосприятия, отражённого в «Свитязянке», а также способствовать уточнению общей эстетики и ряда образов поэзии А. Мицкевича как местного уроженца. Тексты поэта в большинстве случаев читать просто, не расшифровывая до кониа всех деталей, не прибегая $к$ комментарию, а испьтывая радость от общения с великим мастером, ощущая грандиозность и изящество поэтических образов и, насколько это возможно в переводах красоту, мелодичность стиха, находя в волновавших поэта чувствах созвучное современному мироощущению ${ }^{10}$. Похоже, настоящая поэзия (и устная, и письменная) не подвластна времени, а успешно хранит историко-культурные ценности своих создателей, аналитиков и интерпретаторов.

Уже в собраниях фольклорных песен середины XIX века близкого друга А. Мицкевича по тайному патриотическому и просветительному сообществу филоматов из числа студентов Виленского университета - Яна Чачота (1796-1847) «Piosnki wieśniacze znad Nemna i Dźwiny» (Вильно, 1846), отражающих традиционную сельскую культуру Понеманья того времени, назван ряд ценных предметов явно

8 Там же, с. 2.

9 В. Мякотин, Адам Мицкевич и его литературная деятельность [Elektronny resurs]. - Rezhym dostupu: https://sv-scena.ru/Buki/Adam-Mitskyevich-Yego-zhiznjj-ilityeraturnaya-dyeyatyeljjnostjj.html. - Data dostupu: 12.02.2021.

10 А. Мицкевич, Стихотворения. Поэмь / пер. с пол.; вступ. статья, сост. и прим.

Б. Стахеева, Москва 1968, с. 2. 
импортного для земель Беларуси того времени происхождения. Тексты многих песен из данного сборника Я. Чачота и других фольклористов, изучающих Понеманье середины XIX века, позднее - ближе к рубежу XIX/XX веков - были переизданы в собраниях фольклориста Павла Шейна (1826-1900), лучшим из которых, в свою очередь, посвятили эксклюзивное издание подборки песен отечественные исследователи-фольклористы Национальной академии наук в середине XX века ${ }^{11}$.

В отобранных Константином Кабашниковым (1927-2012) и Галиной Барташевич (1932 г. р.) текстах издания «Беларускія народныя песні. Са збораў П. Шэйна» из понеманских материалов упомянуты (с адресацией к собранию Я. Чачота) следующие ценные предметы: элитная мебель шляхетской обстановки замков и фольварков - «белае краселка»12; дорогой восточный текстиль - «атла́с» ${ }^{13}$, «шаўковыя пачопкі» ${ }^{14}$, «шаўковая нітачка» ${ }^{15} ;$ предметы роскоши явно из быта шляхты - «зло́та» и «віно́» 16 ; ценная одежда, ювелирные изделия, серебряные монеты и элитный транспорт - «дарагія жупаны, паясы і пярсцені», «та́леры», «карэта» ${ }^{17}$; а также относительно дорогие, но, скорее всего, лишь имитирующие роскошь предметы, задействованные в юмористических, близких к карнавальным традиционных сельских действах Понеманья - «залатыя крылы», «мёд» (как элитный напиток) ${ }^{18}$.

В песне о крепостном праве и рекрутчине с Понеманья «Ой, чаму ж то, пан Хаміцкі у той час не жаніўся», где одной из действующих лиц является легендарная Бондаровна, а также её противник пан Хамицкий, описаны элитная мебель и дорогой восточный текстиль:

А прывёў жа Бандароўну да свэй светлічэнькі,

Пасадзіӱ жа Бандаройну на бельл краселку;

А казаў жа Бандароўне песеньку спяваці,

А сам пайшоў пан Хаміцкі стрэльбу набіваці.

11 Беларускія народныя песні са збораў П. Шэйна / скл. К. Кабашнікаў, Г. Барташэвіч, Мінск 1962, 430 с.

12 Там же, с. 24.

13 Там же, с. 24.

14 Там же, с. 85 .

15 Там же, с. 189.

16 Там же, с. 195.

17 Там же, с. 280.

18 Там же, с. 280. 
- А ці, лепей, Бандаройно, у сырым пяску гніці, Як за мною, за Хаміцкім, у атла́се хадзіці.

- Ой, лепей, пане Хаміцкі, у сырым пяску гніці, Як за панам, за Хаміцкім, у атла́се хадзіці19.

В жнивной понеманской песне «Сцюдзёная раса пала» с упоминанием реки Дунай (несмотря на то что в Балтии и в Беларуси она не протекает, песни про Dunojus, Дунай издревле встречаются в фольклоре у литовцев и белорусов) после описания нелёгкой доли жнеи перечислены такие предметы, как вёдра из ценной твёрдой тисовой древесины «цісовыя вядзёркі», а также «пачопкі» (лямки) из шёлковой ткани:
А свекраток пераймаіць
3 иісовылі вядзёркамі,
3 шаўковьмі пачопкамі.
А шлець мяне, маладзіцу,
У Дунай па вадзіцу ${ }^{20}$.

В свадебной песне «І шаўковая нітачка» из деревни Крутовцы Новогрудского повета про явно сказочно-мифологическое общение девушки и волка (который в песне умеет говорить) упомянута шёлковая нить - «шаўковая нітачка»:

\author{
I шаўковая нітачка \\ У сцяну б'е. \\ Дзеванька ваўчаньку дабра́нац дае. \\ Да не той дабранац, \\ Што нанач; \\ I да той дабранац, \\ Што на ўвесь век ${ }^{21}$.
}

В свадебной песне «Адчыні, свякратка, вароты» про праздничную встречу свадебного поезда молодых, записанную в Новогрудском повете, невеста уподоблена золоту - «злота», а также упоминаются «віно» и «мёд» (как ферментированный праздничный ритуальный напиток):

\footnotetext{
19 Там же, с. 24.

20 Там же, с. 85.

21 Там же, с. 189.
} 
Адчыні, свякратка, варота,

Бо едзе нявехна, як злота (...).

А яго матка сустрачае,

Сваю нявехну, віном-мёдам вітае:

- Да нявехно ж мая,

Да маладзенька,

Да не будзь хлусліва,

Будзь шчасліва 22 .

В семейно-бытовой песне из Новогрудка «Далеча слыхаць вяліка навіна» про перипетии взаимоотношений парня по имени Петрусь с вельможной пани перечисляется ряд ценных предметов одежды, бытовых атрибутов («дарагія жупаны», «дарагія паясы», «дарагія пярсцені»), серебрянные монеты («та́леры») и конный экипаж («карэта»):

- Уцякай, Пятрусь, уцякай, сэрданька,

Як цябе паймаюць, будзе табе міленька. (...)

Узялі Пятруся за белы бокі,

Укінулі Пятруся у Дунай глыбокі.

- О, дзе твае, Пятрусь, дарагія жупаньи,

Што табе спраўляла вяльможная пані?

Дзе твае, Пятрусь, дарагія паясы,

Што табе спраўляла вяльможная з прывязі?

А дзе твае, Пятрусь, дарагія пярсцені,

Што табе давала вяльможная ў пасцелі? (...)

Вяльможная пані рыбакоў ззывала,

На дзень па талеру каждаму давала (...)

Вяльможная пані да карэты сядала,

Белыя ножанькі аб камень збівала ${ }^{23}$.

В шуточной плясовой дударской песне «Шчыглік невялікі грамаду збірае» с принеманских мест про «птичью свадьбу» (излюбленный сюжет белорусских волынщиков-дударей, название музыкального инструмента которых «дуда» перекликается с названием аналогичного польского инструмента «dudy» 24 - польского аналога волынки, «одного из древнейших народных инструментов» ${ }^{25}$ поляков) упоминаются

22 Там же, с. 195.

23 Там же, с. 280.

24 J. Habela, Stowniczek muzyczny, red. cyklu M. Tomashewski, okładka i rysunki J. Bruchnalski, wydanie czwarte, Kraków 1965, c. 33.

25 Там же, с. 33. 
имитирующие ценность «залатыя крылы» кукушки (скорее всего, просто покрытые фольгой золотистого цвета), а также старинный ферментированный праздничный напиток на меду - «мёд»:

А зязюлька важніца, харошая пціца

Залатыля крылль мае, так гучна лятае,

А чмель мёду давае і госці прымае ${ }^{26}$.

Как видим, в изданиях и фольклорных сводах XIX - начала XX веков ценные предметы периодически и разнообразно упоминаются в текстах народных песен, зафиксированных на части Понеманья, прилегающей к Заосью, Валевке, Новогрудку, Несвижу и их окресностям - местам, которые являются регионом малой родины А. Мицкевича.

В конце XX - начале XXI веков коллектив исследователей лаборатории традиционного искусства Белорусского государственного института проблем культуры, анализировавших «синхронный срез» современной традиции различных регионов Беларуси ${ }^{27}$, в том числе и Новогрудчины в фольклорном своде «Традыцыйная мастацкая культура беларусаў ${ }^{28}$, общаясь с местными носителями традиции: Лаврентием Моничем (село Гнесичи Новогрудского района), Еленой Ващило (село Новины Новогрудского района) и др., зафиксировали на землях, прилегающих к родине А. Мицкевича, следующие упоминания памятников архитектуры и ценных предметов в текстах народных песен: «за́мак», «загародка пазлачана», «брама падуняна» (подъёмный мост либо ворота), «шубёнка»; также упоминаются связанные с культом сакральной чистоты и ритуальным праздничным столом «белая пасьцеленка» (праздничное постельное бельё из выбеленного льна) и «сыр», обязательный в праздничном меню, в отличие от постного, и распространенный у богатых слоев общества и зажиточных крестьян.

Участники волочёбного обхода на Пасху из деревни Заполле Новогрудского района (здесь их зовут «кукальнікі») пели хозяину дома,

26 Беларускія народныя песні са збораў П. Шэйна, скл. К. Кабашнікаў, Г. Барташэвіч, Мінск 1962, с. 333.

27 Традыцыйная мастацкая культура беларусай. У 6 т., А. Боганева [і інш.]; аўт. ідэі Т. Варфаламеева; агул. рэд. Т. Варфаламеевай, Мінск 2006, т. 3. Гродзенскае Панямонне: у 2-х кн., кн. 2. Карагоды - Традыцыйны тэкстыль, с. 4.

28 Традыцыйная мастацкая культура беларусаў: у 6 т. / В. Басько [і інш.]; аўт. ідэі Т. Варфаламеева; агул. рэд. Т. Варфаламеевай. Мінск 2006, т. 3. Гродзенскае Панямонне: у 2-х кн., кн. 1. Каляндарныя святы, звычаі і абрады - Інструментальная музыка, $608 \mathrm{c.}$ 
в который пришли с поздравлениями, упоминая «за́мок», а также поднятые ворота с позолоченной решёткой («загародкай пазлачанай») в песне «Добры вечар, пане-гаспадару»:

\footnotetext{
Засьпяваем песьню вяльможнаму пану.

А у нашага пана тын тынаваны, У тваім ганку, як у за́мку:

Твая брама падуняна, Загародка пазлачана ${ }^{29}$.
}

Текст жнивной песни (исполнители охарактеризовали её как «ле-

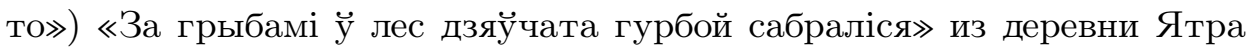
Новогрудского района упоминает меховую верхнюю одежду (шубу) - «шубёнку»:
Вот і осень на праходзі,
Дзевушка ўсё ждёт,
Пад яе закрытым сэрцам
Горушка расцёт.
Ні баялась ана Бога,
Ні роднаго ойца,
I накінула шубёнку,
В лес ана пашла ${ }^{30}$.

Ещё одна жнивная песня (также охарактеризованная как «лето») «Ох вы, жнейкі, мае жнейкі» из той же деревни описывает «белую пасьцеленьку» (из «облагороженного» отбелённого, а не зеленовато-серого, не отбелённого, использующегося в повседневности льна), имеющую символику сакральной праздничной чистоты:

Ох вы, жнейкі, мае жнейкі,

За гарою мае і жменькі.

Альбо мяне падажнеця,

Альбо мяне падаждзеця,

На цёплую вячэраньку,

На белую пасьцеленьку.

Ой, пайду я каля луга,

Шукаючы свайго друга ${ }^{31}$.

\footnotetext{
29 Там же, с. 158.

30 Там же, с. 229.

31 Там же, с. 222.
} 
Следует отметить, что специалисты, описывая льняную ткань, отмечают её «высокую воздухопроницаемость», а также ряд целебных свойств $^{32}$, которые носители фольклора, веками целенаправленно изготовляющие праздничный традиционный текстиль из отбелённого льна, прекрасно знали и высоко ценили.

Весенняя песня «Вол бушуя - вясну чуя» из деревни Туличево Новогрудского района неоднократно упоминает «сыр» как подчёркнуто праздничную еду (в весенний пост молочные продукты были под строгим запретом):

Воран грача - сыра хоча,
Дзеўка плача - замуж хоча. (...)
Не плач, дзейка, пойдзеш замуж,
Ды замужам нажывесься.
Воран грача, сыла зь'еўшы,
Дзеўка плача, сына меўшы
З3.

Конечно же, формально сыр не относится к ценным предметам, но как часть праздничного более «богатого» по сравнению с повседневным (а также с постным) традиционным меню селян кажется достойным упоминания.

Обобщая содержание статьи, отметим, что в белорусских народных песнях с родины Адама Мицкевича, зафиксированных в XIX - начале XX веков, описываются разнообразные ценные предметы: элитная мебель из явно шляхетной обстановки замков и фольварков, восточный текстиль, предметы роскошного каждодневного обихода, ценная одежда и ювелирные изделия, серебряные монеты и элитный транспорт, а также относительно дорогие, но, скорее всего, лишь имитирующие ценность предметы, задействованные в близких к карнавальным традиционных сельских действах. В более поздних фиксациях рубежа XX/XXI веков тезаурус дорогих предметов сокращается, но имеют место упоминания памятников замко-парковой архитектуры и ценных предметов обихода, а также перечисляются более скромные, но связанные с ритуальным праздничным столом и культом сакральной чистоты артефакты традиционной культуры белорусов. Все указанные

32 Tkanina lniana naturalna [Elektronny resurs]. - Rezhym dostupu: https://www.pin sola.pl/tkanina-lniana-naturalna. - Data dostupu: 12.02.2021.

33 Традыцыйная мастацкая культура беларусай: у 6 т. / В. Басько [і інш.]; аўт. ідэі Т. Варфаламеева; агул. рэд. Т. Варфаламеевай. Мінск 2006, т. 3. Гродзенскае Панямонне: у 2-х кн., кн. 1. Каляндарньля святы, звьчаі $і$ абрады - Інструментальная музыка, с. 178. 
предметы выступают символами красоты и комфорта, отражая европейские эстетические идеалы носителей фольклора Гродненского Понеманья.

\section{LITERATURA}

Bielaruskija narodnyja piesni sa zboraŭ P. Šejna / skl. K. Kabašnikaŭ, H. Bartaševič, Minsk 1962 [Беларускія народныя песні са збораў П. Шэйна, скл. К. Кабашнікаў, Г. Барташэвіч, Мінск 1962].

Варрава А., Шлях Мицкевича. Часть 3. [Elektronny resurs]. - Rezhym dostupu: https://planetabelarus.by/publications/shlyakh-mitskevicha-chast-3/. - Data dostupu: 12.02.2021 [Varrava A., Šliach Mickieviča. Častka 3. [Elektronny resurs]. - Rezhym dostupu: https://planetabelarus.by/publications/shlyakhmitskevicha-chast-3/. - Data dostupu: 12.02.2021].

Doŭnar-Zapoĺski M., Historyja Bielarusi, Minsk 2005 [Довнар-Запольский М., История Белоруссии, Минск 2005].

Karatkievič U., Čorny zamak Aĺšanski. Dzikaje paliavannie karalia Stacha, Minsk 1984. [Короткевич В., Чёрный замок Ольшанский. Дикая охота короля Стаха, Минск 1984].

Mickievič A., Vieršy. Paemy / pier. z pol.; ustup. artykul, sost. i zaŭv. B. Stachiejeva; ill.: F. Kanstancinaŭ, Moskva 1968 [Мицкевич A., Стихотворения. Поэмь / пер. с пол.; вступ. статья, сост. и примеч. ил.: Ф. Константинов, Москва 1968].

Miakotin V., Adam Mickievič i jaho litaraturnaja dziejnasć [Eliektronny resurs]. - Rezhym dostupu: https://sv-scena.ru/Buki/Adam-Mitskyevich-Yego-zhiznjji-lityeraturnaya-dyeyatyeljjnostjj.html. - Data dostupu: 12.02.2021 [Мякотин В., Адам Мицкевич и его литературная деятельность [Elektronny resurs]. - Rezhym dostupu: https://sv-scena.ru/Buki/Adam-MitskyevichYego-zhiznjj-i-lityeraturnaya-dyeyatyeljjnostjj.html. - Data dostupu: 12.02. 2021].

Tradycyjnaja Mastackaja kultura bielarusaŭ: u 6 t. / V. Baśko [i inš.]; aŭt. idei T. Varfalamiejeva; ahul. red. T. Varfalamiejeva, Minsk 2006, t. 3. Hrodzienskaj Paniamonnie: u 2-ch kn., kn. 1. Kaliandarnyja śviatyja, zvyčai i abrady - Instrumientaĺnaja muzyka [Традьцьйная мастацкая культура беларусай: у 6 т. / В. Басько [і інш.]; аўт. ідэі Т. Варфаламеева; агул. рэд. Т. Варфаламеевай, Мінск 2006, т. 3. Гродзенскае Панямонне: у 2-х кн., кн. 1. Каляндарныя святы, звьчаі і абрады - Інструментальная музь$\kappa a]$.

Tradycyjnaja Mastackaja kultura bielarusaŭ: u 6 t. / A. Bohanieva [i inš.]; aŭt. idei T. Varfalamiejeva; ahul. red. T. Varfalamiejevaj. Minsk 2006 h., t. 3. Hrodzienskaj Paniamonnie: u 2-ch kn., Kn. 2. Karahody - Tradycyjny tekstyí [Традыцыйная мастацкая культура беларусаў: у 6 т. / А. Боганева 
[i інш.] ; аўт. ідэі Т. Варфаламеева; агул. рэд. Т. Варфаламеевай, Мінск 2006, t. 3. Гродзенскае Панямонне: у 2-х кн., кн. 2. Карагоды - Традыивийны тэкстылль].

Ulitionok H., Lichadziedaŭ U., U pošukach stračanaha: malaja radzima vialikaha Adama Mickieviča, "Bielaruś sionnia", 3 marca 2018, s. 8 [Улитёнок Г., Лиходедов В., В поисках утраченного: малая родина великого Адама Мичкевича, "Беларусь сегодня", 3 марта 2018, с. 8].

Habela J., Stowniczek muzyczny / red. cyklu M. Tomashewski, okładka i rysunki J. Bruchnalski, wydanie czwarte, Kraków 1965.

Tkanina lniana naturalna [Eliektronny resurs]. - Rezhym dostupu: https://www. pinsola.pl/tkanina-lniana-naturalna. - Data dostupu: 12.02.2021.

\section{SUMMARY}

\section{VALUABLE ITEMS FROM ADAM MITSKEVICH'S HOMELAND IN BELARUSIAN FOLK SONGS}

The article provides a description and an analysis of the literary context of valuable items in the well-known lyrics of national folk songs of the Belarusian Ponemania. A romantic poet Adam Mitskevich (1798-1855) was born in the land of Ponemania, not far from the town of Novogrudok and Lake Svityaz. In his poems, he borrowed a lot from local folklore - fairy tales, legends, and songs. The article aims to characterize the valuable items described in Belarusian folk songs, recorded in the homeland of Adam Mitskevich, from the perspective of the history of art and antiques.

Key words: valuable items, history of art, antique practice, Belarusian folk songs from the homeland of Adam Mitskevich. 